\title{
Pola konsumsi air, susu dan produk susu, serta minuman manis sebagai faktor risiko obesitas pada anak sekolah dasar di Kota Yogyakarta dan Kabupaten Bantul
}

Yayah Lakoro', Hamam Hadi², Madarina Julia²

\begin{abstract}
Background: Sweet drinks are suspected as the cause of the incidence of obesity in children. Unhealthy milk and milk product containing fat and high glucose can become one of risk factors of the incidence of obesity whereas water is healthy drink without calori that can help manage weight.

Objective: To identify consumption pattern of drinks in obese children.

Method: The study was a case control, involving obese elementary school children as cases and elementary school children with normal weight as control. Locations of the study were Yogyakarta Municipality and District of Bantul. Sampling method used probability proportional to size (PPS). There were 488 samples comprising 244 cases and 244 controls. Matching was made to the school of origin on condition that case and control students were at the same grade. Statistical test used McNemar and logistic regression to identify variables of risk factors.

Result: There was difference in characteristics of gender between the two groups $(p=0.03)$. Average amount of water and sweet drink consumption in obese children significantly differed from non obese children, subsequently $243.8 \mathrm{~mL}$ day ( $\pm 21 / 2$ cup/day) and $397.3 \mathrm{~mL} /$ day ( \pm 2 cup/day), whereas avarage amount of consumption of unhealthy milk and milk product in obese and non obese children showed no significant difference. The result of McNemar test showed that consumption of water and sweet drink was associated with the incidence of obesity in children at Yogyakarta Municipality and District of Bantul with score of OR 2.1 (95\% Cl:1.4-3.05) and OR 3.1 (95\% Cl: 2.1-4.5), whereas consumption of unhealthy milk and milk product showed no significant difference. The result of regression test showed that sweet drink was dominant risk factor of the incidence of obesity in children $\left(R^{2}=0.071\right)$.

Conclusion: Consumption of water and sweet drink was associated with the incidence of obesity in children. Consumption of sweet drink could affect consumption of water, whereby higher comsumption of sweet drink meant lower consumption of water. Nutrition education embedded in the curriculum could be used as an alternative of obesity prevention in children by changing or building healthy lifestyle.
\end{abstract}

KEYWORDS: risk factors, obese children, consumption of water, consumption of sweet drink

\begin{abstract}
ABSTRAK
Latar belakang: Minuman manis diduga kuat sebagai penyebab terjadinya obesitas pada anak. Susu dan produk susu yang tidak sehat yang mengandung lemak dan gula tinggi dapat menjadi salah satu faktor risiko terjadinya obesitas, sedangkan air putih merupakan minuman sehat tanpa kalori yang dapat membantu manajemen berat badan.

Tujuan: Mengetahui pola konsumsi minuman pada anak obesitas.

Metode: Penelitian ini merupakan penelitian kasus kontrol. Kasus adalah anak SD yang mengalami obesitas, kontrol adalah anak SD yang dengan berat badan normal. Lokasi penelitian di Kota Yogyakarta dan Kabupaten Bantul. Penentuan sampel menggunakan metode probability proportional to size (PPS). Jumlah sampel adalah 488 sampel terdiri dari 244 kasus dan 244 kontrol. Pada subyek penelitian dilakukan matching asal sekolah dengan ketentuan siswa kasus dan kontrol berasal dari kelas yang sama. Uji statistic McNemar dan regresi logistik dilakukan untuk mengidentifikasi variabel yang merupakan faktor risiko.

Hasil: Terdapat perbedaan karakteristik jenis kelamin antara kedua kelompok ( $p=0,03)$. Rata-rata jumlah konsumsi air putih dan minuman manis pada anak obes berbeda secara signifikan dibandingkan dengan anak tidak obes, berturutturut adalah 243,8 mL/hari ( $\pm 21 / 2$ gelas/hari) dan 397,3 mL/hari ( \pm 2 gelas/hari), sedangkan rata-rata jumlah konsumsi susu dan produk susu tidak sehat pada anak obes dan tidak obes, tidak berbeda secara signifikan. Uji Mc Nemar menunjukkan bahwa konsumsi air putih dan minuman manis berhubungan dengan kejadian obesitas pada anak di Kota Yogyakarta dan Kabupaten Bantul dengan nilai OR 2,1 (95\% Cl:1,4-3,05) dan OR 3,1 (95\% Cl: 2,1-4,5), sedangkan
\end{abstract}

\footnotetext{
1 Pasca Sarjana Gizi dan Kesehatan Fakultas Kedokteran Universitas Gadjah Mada, Jl.Farmako, Sekip Utara Yogyakarta 55281, email: yayahlakoro12@ gmail.com

2 Magister Gizi dan Kesehatan Fakultas Kedokteran Universitas Gadjah Mada, Jl.Farmako, Sekip Utara Yogyakarta 55281, email: hamamhadi99@gmail. com

${ }^{3}$ Bagian IImu Kesehatan Anak FK-UGM/ SMF IImu Kesehatan Anak RSUP Dr. Sardjito JI. Kesehatan No. 1 Yogyakarta, email: madarinajulia@yahoo.com
} 
pada konsumsi susu dan produk susu tidak sehat tidak berbeda secara signifikan. Uji regresi menunjukkan bahwa minuman manis merupakan faktor risiko dominan terhadap kejadian obesitas pada anak $\left(R^{2}=0,071\right)$.

Kesimpulan: Konsumsi air putih dan minuman manis berhubungan dengan kejadian obesitas pada anak bahwa konsumsi minuman manis dapat mempengaruhi konsumsi air putih. Semakin tinggi konsumsi minuman manis, maka konsumsi air putih akan semakin rendah. Pendidikan gizi yang dimasukkan dalam kurikulum sekolah dapat dijadikan alternatif pencegahan obesitas pada anak dengan cara mengubah atau membentuk gaya hidup sehat.

KATA KUNCI : faktor risiko, obesitas anak, konsumsi minuman, minuman manis

\section{PENDAHULUAN}

Obesitas atau kegemukan merupakan penyakit multifaktorial yang tidak hanya ditemukan pada penduduk dewasa tetapi juga pada anak-anak dan remaja. Penelitian mengenai obesitas pada anak-anak usia sekolah dasar dengan prevalensi secara berurutan dari yang tertinggi ialah Jakarta (25\%), Semarang (24,3\%), Medan (17,75\%), Denpasar $(11,7 \%)$, Surabaya $(11,4 \%)$, Padang $(7,1 \%)$, Manado (5,3\%), Yogyakarta (4\%), dan Solo (2,1\%). Ratarata prevalensi kegemukan pada anak sekolah dasar di 10 kota besar di Indonesia mencapai 12,2\% (1). Di Yogyakarta, prevalensi obesitas pada anak mencapai $9,7 \%$ dan penelitian lainnya menemukan bahwa $7,8 \%$ remaja diperkotaan dan $2 \%$ remaja di pedesaan mengalami obesitas (2).

Kegemukan dikaitkan dengan sejumlah penyakit penyerta pada anak-anak, meskipun data tentang penyakit penyerta obesitas pada anak ini sangat kurang dibandingkan dengan data penyakit penyerta obesitas pada orang dewasa, namun efek merugikan dari kegemukan pada anak mirip dengan orang dewasa (3). Obesitas dalam penelitian ini dihubungkan dengan konsumsi minuman pada anak yaitu konsumsi air putih, susu dan produk susu, serta minuman manis. Menurut hasil Riskesdas tahun 2010, pada kelompok usia remaja, dewasa wanita, dan dewasa pria, rata-rata pemenuhan asupan air berturut-turut adalah $71.5 \% \pm 29,4 \%, 79,9 \% \pm 31,7 \%$, dan $64,8 \% \pm 23,3 \%$. Penemuan ini sejalan dengan hasil studi tahun 2010 yang menilai kecukupan asupan air penduduk Indonesia berdasarkan indikator. Hasil penelitian tersebut membuktikan besarnya masalah dehidrasi ringan di kalangan penduduk Indonesia yaitu $46,1 \%$ dan 1 di antara 2 remaja indonesia mengalami dehidrasi ringan (4).

Susu dan produk susu merupakan sumber kalsium utama dalam diet orang Amerika dengan kontribusi kalsium dari sumber tersebut sebesar $70 \%$. Enam puluh tahun yang lalu, asupan susu orang Amerika 4 kali lebih banyak dibandingkan minuman ringan, namun pada tahun 1998 , asupan minuman ringan $2 \frac{1}{3}$ kali lebih banyak daripada susu. Perubahan ini menunjukkan bahwa asupan susu mulai tergantikan dengan minuman lain. Minuman ringan manis menjadi sumber asupan gula terbesar dalam diet orang Amerika, terutama di kalangan umur 6-19 tahun. Hal ini telah dikaitkan dengan masalah gizi dan kesehatan yang merugikan seperti obesitas, karies gigi, dan penurunan kepadatan tulang (5).
Data dari beberapa penelitian tentang hubungan asupan kalsium dengan berat badan dan lemak tubuh menunjukkan bahwa peningkatan konsumsi kalsium yang setara dengan 2 gelas susu per hari secara teratur dapat mengurangi risiko kelebihan berat badan hingga $70 \%$ (6). Dalam sebuah studi longitudinal pada anak-anak, konsumsi makanan tinggi kalsium dan konsumsi susu setiap hari mempunyai hubungan negatif dengan kadar lemak tubuh anak $(7,8)$. Asupan kalsium juga mengurangi risiko resistensi insulin sebanyak $21 \%$ pada remaja yang kelebihan berat badan dan dapat juga mengurangi risiko diabetes (9).

Pola konsumsi minuman manis pada anak-anak dan remaja di berbagai negara belakangan ini sangat meningkat. Data dari Departemen Pertanian Amerika serikat mencatat bahwa konsumsi meningkat sangat tajam dalam 50 tahun terakhir. Konsumsi meningkat dari $195 \mathrm{~mL}$ per hari menjadi $275 \mathrm{~mL}$ per hari pada total populasi, pada anak usia sekolah konsumsi minuman ringan ini adalah $265 \mathrm{~mL}$ atau lebih per hari (10). Pola konsumsi telah banyak dikaitkan dengan kegemukan pada anak, asupan jus buah konsentrat dan minuman manis merupakan sumber potensial yang dikaitkan dengan prevalensi obesitas pada anak (11).

\section{BAHAN DAN METODE}

Penelitian ini merupakan penelitian kasus-kontrol yang berlokasi di Kabupaten Bantul dan Kota Yogjakarta. Penelitian ini berlangsung dari bulan Januari hingga Juni tahun 2013. Kasus yang diambil adalah anak yang teridentifikasi obesitas pada saat dilakukan skrining. Kontrol adalah anak dengan berat badan normal yang berasal dari sekolah dan kelas yang sama dengan kasus. Perbandingan kasus kontrol adalah 1:1, sampel penelitian dipilih dengan menggunakan metode (12).

Penelitian ini telah mendapatkan persetujuan dan kelaikan penelitian dari Komite Etik Fakultas Kedokteran UGM tanggal 10 April 2013 Ref: KE/FK/352/EC. Penentuan Indeks massa tubuh (IMT) yang digunakan dalam penelitian ini adalah kurva rujukan WHO 2007 dengan nilai persentil $\geq 95 \%$ untuk anak dengan kategori obesitas. Data konsumsi minuman diambil dengan menggunakan formulir 3×24 jam, terdiri dari 2 hari, yaitu 1 hari aktif sekolah dan 1 hari libur. Konsumsi minuman digolongkan berdasarkan jenisnya, yaitu air putih, susu dan produk susu, serta minuman manis. Konsumsi air putih dibandingkan dengan Angka Kecukupan Gizi (AKG) 2012, sesuai dengan kelompok umur anak (13). 
Konsumsi susu dan produk susu dibandingkan dengan anjuran minum susu sebanyak 2 gelas $(400 \mathrm{~mL})$ per hari, serta dihitung asupan kalori dari susu dan produk susu yang diminum oleh anak. Konsumsi minuman manis dihitung berdasarkan jumlah porsi (gelas) dari segala jenis minuman manis yang dikonsumsi oleh anak .

Uji digunakan untuk melihat perbedaan karakteristik dasar subjek, uji Mc Nemar untuk melihat variable-variabel yang diteliti merupakan faktor risiko obesitas atau tidak, dan uji regresi logistik digunakan untuk menentukan faktor risiko dominan pada kejadian obesitas anak. Analisis data menggunakan perangkat lunak komputer STATA (Stata Corp LP,Texas).

\section{HASIL}

Subjek penelitian sebanyak 488 anak SD di Yogyakarta dan Bantul yang terdiri dari 244 subjek kelompok kasus (obesitas) dan 244 subjek kelompok kontrol. Pemilihan 244 siswa obes berdasarkan proporsi jenis kota dari hasil skrining yaitu 5,23\% untuk kota besar, $13,61 \%$ di kota kecil $71,46 \%$, dan $9,70 \%$ di desa. Pada subjek penelitian dilakukan asal sekolah dengan ketentuan siswa kasus dan kontrol berasal dari kelas yang sama. Seluruh subjek penelitian berasal dari sekolah yang terdaftar pada Dinas Pendidikan Kota Yogyakarta dan Kabupaten Bantul.

Tabel 1 menggambarkan karakteristik responden yang berbeda signifikan adalah jenis kelamin dan obesitas lebih banyak terjadi pada anak laki-laki dibandingkan anak perempuan $(p=0,003)$. Tabel 2 menunjukkan perbedaan konsumsi air putih kurang dari kecukupan air yang dianjurkan terdapat pada kelompok siswa obes $(67,2 \%)$, dengan OR 2,1 (95\%Cl: 1,4-3,05). Untuk variabel susu dan produk susu yang tidak sehat yang dikonsumsi dua gelas atau lebih per hari pada kelompok anak obes sebesar

Tabel 1. Karakteristik subjek penelitian antara kelompok obes dan tidak obes

\begin{tabular}{|c|c|c|c|c|c|c|c|c|}
\hline \multirow{3}{*}{ Karakteristik } & \multicolumn{4}{|c|}{ Status obesitas } & \multirow{2}{*}{\multicolumn{2}{|c|}{ Total }} & \multirow{3}{*}{$\chi^{2}$} & \multirow{3}{*}{$\mathbf{p}$} \\
\hline & \multicolumn{2}{|c|}{ Ya } & \multicolumn{2}{|c|}{ Tidak } & & & & \\
\hline & $\mathbf{N}$ & $\%$ & $\mathbf{n}$ & $\%$ & $\mathbf{n}$ & $\%$ & & \\
\hline \multicolumn{9}{|l|}{ Kelompok usia } \\
\hline $6-8$ tahun & 84 & 34,43 & 83 & 34,02 & 167 & 34,22 & 0,29 & 0,86 \\
\hline $9-10$ tahun & 114 & 46,72 & 119 & 48,77 & 233 & 47,75 & & \\
\hline 11-12 tahun & 46 & 17,21 & 42 & 17,21 & 88 & 18,03 & & \\
\hline \multicolumn{9}{|l|}{ Jenis kelamin } \\
\hline Laki-laki & 154 & 63,11 & 122 & 50,00 & 276 & 56,56 & 8,54 & 0,003 \\
\hline Perempuan & 90 & 36,89 & 122 & 50,00 & 212 & 43,44 & & \\
\hline \multicolumn{9}{|l|}{ Tempat tinggal } \\
\hline Kota besar & 13 & 5,33 & 19 & 7,79 & 32 & 6,56 & 2,91 & 0,40 \\
\hline Kota sedang & 34 & 13,93 & 43 & 17,62 & 77 & 15,78 & & \\
\hline Kota kecil & 174 & 71,31 & 163 & 66,80 & 337 & 69,06 & & \\
\hline Desa & 23 & 9,43 & 19 & 7,79 & 42 & 8,61 & & \\
\hline \multicolumn{9}{|l|}{ Pendidikan ibu } \\
\hline Tinggi & 200 & 81,97 & 191 & 78,28 & 391 & 80,12 & 1,04 & 0,30 \\
\hline Rendah & 44 & 18,03 & 53 & 21,72 & 97 & 19,88 & & \\
\hline \multicolumn{9}{|l|}{ Pekerjaan ibu } \\
\hline Tidak bekerja & 64 & 26,23 & 57 & 23,26 & 121 & 24,80 & 0,53 & 0,46 \\
\hline Bekerja & 180 & 73,77 & 187 & 76,64 & 367 & 75,20 & & \\
\hline \multicolumn{9}{|l|}{ Pendidikan ayah } \\
\hline Tinggi & 208 & 85,25 & 200 & 81,97 & 408 & 83,61 & 0,95 & 0,32 \\
\hline Rendah & 36 & 14,75 & 44 & 18,03 & 80 & 16,39 & & \\
\hline \multicolumn{9}{|l|}{ Pekerjaan ayah } \\
\hline Petani//nelayan & 2 & 0,83 & 3 & 1,24 & 5 & 1,03 & 7,16 & 0,30 \\
\hline Buruh/buruh tani & 21 & 8,68 & 36 & 14,88 & 57 & 11,78 & & \\
\hline Karyawan swasta & 70 & 28,93 & 71 & 29,34 & 141 & 29,13 & & \\
\hline PNS/TNI/POLRI & 39 & 16,12 & 31 & 12,81 & 70 & 14,46 & & \\
\hline Wiraswasta & 93 & 38,43 & 80 & 33,06 & 173 & 35,74 & & \\
\hline Tidak bekerja/IRT & 1 & 0,41 & 3 & 1,24 & 4 & 0,83 & & \\
\hline Lainnya & 16 & 6,61 & 18 & 7,44 & 34 & 7,02 & & \\
\hline \multicolumn{9}{|l|}{ Pengeluaran keluarga } \\
\hline$\leq$ UMR & 20 & 8,20 & 22 & 90,98 & 446 & 91,39 & 0,10 & 0,74 \\
\hline$>$ UMR & 224 & 91,80 & 222 & 9,02 & 42 & 8,61 & & \\
\hline \multicolumn{9}{|c|}{ Jumlah anggota keluarga } \\
\hline$>4$ orang & 96 & 39,34 & 99 & 40,57 & 195 & 60,04 & 0,07 & 0,78 \\
\hline$\leq 4$ orang & 148 & 60,66 & 145 & 59,43 & 293 & 39,96 & & \\
\hline
\end{tabular}


Tabel 2 . Analisis Mc Nemar jumlah konsumsi air putih, susu dan produk susu, serta minuman manis pada anak

\begin{tabular}{|c|c|c|c|c|c|c|c|c|}
\hline \multirow{2}{*}{ Variabel } & \multicolumn{4}{|c|}{ Status obesitas } & \multirow{2}{*}{ OR } & \multirow{2}{*}{$95 \% \mathrm{Cl}$} & \multirow[b]{2}{*}{$\chi^{2}$} & \multirow[b]{2}{*}{ p } \\
\hline & $Y a$ & $\%$ & Tidak & $\%$ & & & & \\
\hline \multicolumn{9}{|l|}{ Air putih } \\
\hline Kurang & 164 & 67,2 & 121 & 49,6 & 2,1 & $1,4-3,05$ & 15,6 & 0,0001 \\
\hline Cukup & 80 & 32,8 & 123 & 50,4 & & & & \\
\hline \multicolumn{9}{|l|}{ Susu dan olahan } \\
\hline$\geq 400 \mathrm{~mL} /$ hari & 12 & 4,9 & 9 & 3,7 & 0,7 & $0,3-1,9$ & 0,4 & 0,50 \\
\hline$<400 \mathrm{~mL} /$ hari & 232 & 95,1 & 235 & 96,3 & & & & \\
\hline \multicolumn{9}{|l|}{ Minuman manis } \\
\hline$\geq 200 \mathrm{~mL}$ /hari & 148 & 60,7 & 96 & 39,3 & 3,1 & $2,1-4,5$ & 56,9 & $<0,001$ \\
\hline$<200 \mathrm{~mL}$ /hari & 81 & 33,3 & 163 & 66,7 & & & & \\
\hline
\end{tabular}

Kecukupan air menurut kelompok umur:

Umur 4-6 tahun $=1500 \mathrm{~mL} / \mathrm{hari}$

Umur 7-9 tahun $=1800 \mathrm{~mL} / \mathrm{hari}$

Umur $10-12$ tahun $=1900 \mathrm{~mL} /$ hari (laki-laki dan perempuan)

Umur 13-15 tahun $=2000 \mathrm{~mL} /$ hari (laki-laki dan perempuan)

Tabel 3. Perbedaan rata-rata konsumsi air putih, susu dan produk susu, serta minuman manis berdasarkan wilayah

\begin{tabular}{|c|c|c|c|c|}
\hline Variabel & $\begin{array}{c}\text { Obes } \\
\text { mean } \pm S D\end{array}$ & $\begin{array}{c}\text { Tidak obes } \\
\text { mean } \pm S D\end{array}$ & $\begin{array}{c}\text { Perbedaan mean } \\
(95 \% \mathrm{Cl}) \\
\end{array}$ & $\mathbf{p}$ \\
\hline \multicolumn{5}{|l|}{ Yogyakarta } \\
\hline Air putih (mL/hari) & $1.493,2 \pm 529,6$ & $1.893,9 \pm 572,2$ & $400,7(281,7-519,7)$ & $<0,001$ \\
\hline Susu dan produk susu (mL/hari) & $328,9 \pm 390,7$ & $248,3 \pm 365,2$ & $80,7(-1,1-162,3)$ & 0,03 \\
\hline Minuman manis (mL/hari) & $1.066,1 \pm 766,7$ & $490,4 \pm 479,6$ & $575,7 \quad(437,6-713,7)$ & $<0,001$ \\
\hline \multicolumn{5}{|l|}{ Bantul } \\
\hline Air putih (mL/hari) & $1.805,8 \pm 1958,7$ & $1.715,9 \pm 641,4$ & $89,9(-371,1-550,9)$ & 0,65 \\
\hline Susu dan produk susu (mL/hari) & $229,3 \pm 339,9$ & $347,8 \pm 370,6$ & $118,5(6,01-230,9)$ & 0,98 \\
\hline Minuman manis (mL/hari) & $882,9 \pm 698,2$ & $865,4 \pm 698,2$ & $17,6(-206,56-241,7)$ & 0,44 \\
\hline \multicolumn{5}{|l|}{ Total } \\
\hline Air putih (mL/hari) & $1.593,1 \pm 1.194,7$ & $1.837,1 \pm 599,6$ & $243,8(75,7-412)$ & 0,002 \\
\hline Susu dan produk susu (mL/hari) & $297,1 \pm 377,4$ & $280,1 \pm 369,1$ & $16,9(-49,4-83,4)$ & 0,31 \\
\hline Minuman manis (mL/hari) & $1.007,5 \pm 748,9$ & $610,3 \pm 1.007,5$ & $397,3(277,2-517,3)$ & $<0,001$ \\
\hline
\end{tabular}

$4,9 \%$, sedangkan pada anak yang tidak obes sebesar $3,69 \%$, namun secara statistik tidak ada perbedaan yang signifikan. Untuk variabel minuman manis lebih dari 200 $\mathrm{mL}$ per hari, pada kelompok kasus lebih tinggi $(60,66 \%)$ dibandingkan pada kelompok kontrol $(39,3 \%)$ dengan OR 3,1 (95\% Cl: 2,1-4,5).

Pada Tabel 3 dengan menggunakan uji t dapat dilihat rata-rata konsumsi air putih di Kota Yogyakarta pada anak obes dengan rata-rata perbedaan kurang lebih 400,7 mL ( 2 gelas) per hari, namun di Kabupaten Bantul jumlah konsumsi air putih pada anak obes tidak jauh berbeda dengan anak tidak obes, dengan rata-rata perbedaan 89,9 $\mathrm{mL}$ (kurang dari $1 / 2$ gelas) per hari.

Rata-rata konsumsi susu dan produk susu yang tidak sehat di Kota Yogyakarta pada anak obes lebih banyak dibanding anak tidak obes dengan rata-rata perbedaan $80,7 \mathrm{~mL}$ (kurang dari 1/2 gelas) per hari, sedangkan untuk Kabupaten Bantul anak obes lebih sedikit mengkonsumsi susu dan produk susu yang tidak sehat dibandingkan dengan anak yang tidak obes dengan perbedaan rata- rata $118,5 \mathrm{~mL}\left( \pm \frac{1}{2}\right.$ gelas) per hari namun secara statistik perbedaan ini tidak berbeda signifikan $(p>0,05)$.

Rata-rata konsumsi minuman manis pada anak obes di Kota Yogyakarta lebih banyak dibandingkan dengan anak yang tidak obes dengan perbedaan rata-rata 575,7 $\mathrm{mL}\left( \pm 2 \frac{1}{2}\right.$ gelas) per hari, sedangkan di Kabupaten Bantul rata-rata konsumsi minuman manis pada anak tidak berbeda dengan rata-rata konsumsi minuman manis pada anak tidak obes $(p>0,05)$.

Secara keseluruhan, rata-rata jumlah konsumsi air putih dan minuman manis di Kota Yogyakata dan Kabupaten Bantul pada anak obes berbeda signifikan dibandingkan dengan anak tidak obes $(p<0,05)$, sedangkan rata-rata jumlah konsumsi susu dan produk susu tidak sehat pada anak obes dan tidak obes tidak berbeda signifikan $(p>0,05)$.

Pada Tabel 4 dapat dilihat perbedaan rata-rata konsumsi air putih, susu dan produk susu serta minuman manis pada anak obes dan tidak obes berdasarkan jenis kota. Rata-rata jumlah konsumsi air putih pada anak obes 
Tabel 4. Tabel perbedaan rata-rata konsumsi air putih, susu dan produk susu, serta minuman manis berdasarkan jenis kota

\begin{tabular}{|c|c|c|c|c|}
\hline \multirow{2}{*}{ Variabel } & \multirow{2}{*}{$\begin{array}{c}\text { Obes } \\
\text { mean } \pm S D\end{array}$} & \multirow{2}{*}{$\begin{array}{l}\text { Tidak obes } \\
\text { mean } \pm S D\end{array}$} & \multirow{2}{*}{$\begin{array}{l}\text { Perbedaan mean } \\
(95 \% \mathrm{Cl})\end{array}$} & \multirow{2}{*}{$\mathbf{p}$} \\
\hline & & & & \\
\hline \multicolumn{5}{|l|}{ Kota besar } \\
\hline Air putih (mL/hari) & $1.391,4 \pm 501,5$ & $1.849 \pm 580,5$ & $457,6(53,03-862,1)$ & 0,01 \\
\hline Susu dan produk susu (mL/hari) & $322,6 \pm 364,4$ & $229,1 \pm 314,4$ & $93,5(-152,9-340)$ & 0,22 \\
\hline Minuman manis (mL/hari) & $1.090,1 \pm 828,2$ & $350,7 \pm 321,8$ & $739,3(312,9-1166,7)$ & $<0,001$ \\
\hline \multicolumn{5}{|l|}{ Kota sedang } \\
\hline Air putih (mL/hari) & $1.805,9 \pm 1.958,8$ & $1.817,8 \pm 619,9$ & $294,8(20,8-568,8)$ & 0,02 \\
\hline Susu dan produk susu (mL/hari) & $322,6 \pm 364,4$ & $245,7 \pm 444,5$ & $137,2(-66,7-3441,2)$ & 0,09 \\
\hline Minuman manis (mL/hari) & $979,2 \pm 803,2$ & $573,4 \pm 554,1$ & $405,8(97,2-714,4)$ & 0,005 \\
\hline \multicolumn{5}{|l|}{ Kota kecil } \\
\hline Air putih (mL/hari) & $1.622,4 \pm 1.372,7$ & $1.834 .3 \pm 599,4$ & $211,9(-17,7-441.5)$ & 0,04 \\
\hline Susu dan produk susu (mL/hari) & $286,2 \pm 370,8$ & $278.9 \pm 335,1$ & $7,2(-83,1-68,7)$ & 0,43 \\
\hline Minuman manis (mL/hari) & $1.020,2 \pm 744,6$ & $646.3 \pm 620,2$ & $373,8(266,5-521,2)$ & $<0,001$ \\
\hline \multicolumn{5}{|l|}{ Desa } \\
\hline Air putih (mL/hari) & $1.589,4 \pm 530,8$ & $1.891,5 \pm 618,5$ & $302,1(-56,3-660,5)$ & 0,05 \\
\hline Susu dan produk susu (mL/hari) & $238,1 \pm 319,1$ & $418,7 \pm 492,5$ & $180,5(-74,1-435,2)$ & 0,92 \\
\hline Minuman manis (mL/hari) & $906,9 \pm 690,9$ & $644,1 \pm 602,9$ & $262,8(-671,8-146,2)$ & 0,10 \\
\hline
\end{tabular}

dan tidak obes berbeda signifikan di daerah kota besar, kota sedang, kota kecil dan desa $(p<0,05)$. Untuk rata-rata konsumsi susu dan produk susu tidak ada perbedaan signifikan menurut jenis kota $(p>0,05)$. Rata-rata konsumsi minuman manis pada anak obes dan tidak obes terdapat perbedaan yang signifikan pada daerah kota besar, kota sedang dan kota kecil $(p<0,05)$, dan untuk daerah desa tidak ada perbedaan yang signifikan antara anak obes dan tidak obes $(p>0,05)$.

Analisis stratifikasi dilakukan untuk melihat hubungan konsumsi air putih dan konsumsi minuman manis dengan obesitas pada strata jenis kelamin. Hasil uji stratifikasi menunjukkan tidak ada perbedaan yang signifikan antara strata jenis kelamin laki-laki dan perempuan $(p>0,05)$, sehingga jenis kelamin bukan merupakan efek modifikasi. Perbedaan OR dengan OR tidak lebih dari 20\% sehingga dapat diketahui bahwa jenis kelamin tidak menjadi variabel perancu bagi hubungan antara antara konsumsi air putih dan konsumsi minuman manis dengan obesitas.

\section{Pengaruh pola minum terhadap terjadinya obesitas}

Uji hipotesis penelitian yang digunakan adalah uji dengan tingkat kemaknaan $\alpha=0,05$ dan $95 \% \mathrm{Cl} .\left(\mathrm{R}^{2}\right)$ digunakan untuk melihat sejauh mana seluruh variabel dalam setiap model memprediksi terjadinya obesitas pada anak SD di Yogyakarta dan Bantul. Analisis logisitik dari variabel untuk melihat model yang paling dominan mempengaruhi kejadian obesitas dapat dilihat pada Tabel 5.

Pada Tabel 5 dapat dilihat pola minum anak dengan kejadian obesitas. Konsumsi air putih pada model 1 menunjukkan bahwa konsumsi air putih yang kurang 2,1 kali berpeluang terjadi pada anak obes dibandingkan anak tidak obes. Model ini dapat memperkirakan kejadian obesitas pada anak sebesar 2,3\% sedangkan 97,7\% disebabkan oleh faktor lain yang tidak diteliti dalam penelitian ini. Pada model 2 dapat dilihat OR variabel air minum yang mengalami penurunan ketika variabel minuman manis diikutsertakan, nilai $\mathrm{R}^{2}$ juga mengalami peningkatan menjadi $6,38 \%$, sehingga dapat dinterpretasikan bahwa semakin banyak anak mengkonsumsi minuman manis maka konsumsi air putih akan menjadi sedikit.

Hasil analisis yang sama terjadi seperti pada model 2 , ketika variabel jenis kelamin sebagai variabel luar diikutsertakan (model 3) nilai $\mathrm{R}^{2}$ meningkat menjadi $7,1 \%$. Dari model ini dapat diketahui bahwa anak dengan jenis kelamin laki-laki berpotensi mengalami obesitas karena konsumsi minuman manis yang lebih banyak dibandingkan dengan air putih. Pada model 4 dapat dilihat konsumsi minuman manis dengan mengikutsertakan variabel jenis kelamin, memperkirakan kejadian obesitas sebesar $6,28 \%$ (OR 2,9) sedangkan tanpa mengikutsertakan variabel luar (model 5) dapat memperkirakan kejadian obesitas pada anak sebesar $5,53 \%$.

Analisis pada variabel air putih menunjukkan bahwa nilai OR semakin kecil jika jumlah konsumsi air putih per hari semakin sering. Jumlah konsumsi air putih kurang dari 8 gelas per hari merupakan faktor risiko obesitas, sedangkan konsumsi air putih 8 gelas atau lebih merupakan faktor protektif terhadap kejadian obesitas pada anak $(O R=0,4)$, sedangkan pada variabel minuman manis menunjukkan bahwa nilai OR semakin besar jika jumlah konsumsi minuman manis per hari semakin sering, sehingga konsumsi minuman manis lebih dari 1 gelas (>200 mL) per hari merupakan faktor risiko terjadinya obesitas (OR 3,6). 
Tabel 5. Pengaruh pola minum terhadap kejadian obesitas berdasarkan model regresi logistik

\begin{tabular}{|c|c|c|c|c|c|}
\hline Variabel & $\begin{array}{c}\text { Model I } \\
\text { OR } \\
(95 \% \mathrm{Cl})\end{array}$ & $\begin{array}{c}\text { Model II } \\
\text { OR } \\
(95 \% \mathrm{Cl})\end{array}$ & $\begin{array}{c}\text { Model III } \\
\text { OR } \\
(95 \% \mathrm{Cl}) \\
\end{array}$ & $\begin{array}{c}\text { Model IV } \\
\text { OR } \\
(95 \% \mathrm{Cl})\end{array}$ & $\begin{array}{c}\text { Model V } \\
\text { OR } \\
(95 \% \mathrm{Cl})\end{array}$ \\
\hline Air Putih & 2,1 & 1,6 & 1,6 & & \\
\hline Kurang (0) & $(1,4-3)$ & $(1,1-2,3)$ & $(1,1-2,3)$ & & \\
\hline Cukup (1) & $p=0,0001$ & $p=0,02$ & $p=0,02$ & & \\
\hline Minuman Manis & & 2,7 & 2,6 & 2,9 & 3,1 \\
\hline$\geq 200 \mathrm{~mL} /$ hari $(0)$ & & $(1,8-4,03)$ & $(1,8-3,9)$ & $(2,04-4,3)$ & $(2,1-4,5)$ \\
\hline$<200 \mathrm{~mL} /$ hari (1) & & $p=<0,001$ & $p=<0,001$ & $p=<0,001$ & $p=<0,001$ \\
\hline Jenis Kelamin & & & 1,5 & 1.5 & \\
\hline Laki-laki (0) & & & $(1,03-2,2)$ & $(1,05-2,2)$ & \\
\hline Perempuan (1) & & & $p=0,03$ & $p=0,03$ & \\
\hline $\mathrm{N}$ & 488 & 488 & 488 & 488 & 488 \\
\hline $\mathrm{R}^{2}$ & 0,023 & 0,063 & 0,071 & 0,062 & 0,055 \\
\hline
\end{tabular}

Ket : $0=$ Terpapar , $1=$ Tidak terpapar

Tabel 11. Dose response jumlah konsumsi air putih dan minuman manis terhadap kejadian obesitas pada anak di Kota Yogjakarta dan Kabupaten Bantul

\begin{tabular}{|c|c|c|c|c|c|c|c|}
\hline \multirow{3}{*}{ Variabel } & \multicolumn{4}{|c|}{ Obesitas } & \multirow{3}{*}{ OR } & \multirow{3}{*}{$95 \% \mathrm{Cl}$} & \multirow{3}{*}{$\mathbf{p}$} \\
\hline & \multicolumn{2}{|c|}{ Ya } & \multicolumn{2}{|c|}{ Tidak } & & & \\
\hline & $\mathbf{n}$ & $\%$ & $\mathbf{n}$ & $\%$ & & & \\
\hline \multicolumn{8}{|l|}{ Air putih } \\
\hline$<5$ gelas per hari & 33 & 13,52 & 13 & 5,33 & 3,8 & $1,9-7,6$ & $<0,001$ \\
\hline$<6$ gelas per hari & 40 & 16,39 & 18 & 7,38 & 3,3 & $1,8-6,2$ & $<0,001$ \\
\hline$<7$ gelas per hari & 37 & 15,16 & 26 & 10,66 & 2,1 & $1,2-3,7$ & 0,008 \\
\hline$<8$ gelas per hari & 35 & 14,34 & 38 & 15,57 & 1,4 & $0,8-2,3$ & 0,223 \\
\hline$\geq 8$ gelas per hari & 99 & 40,57 & 149 & 61,07 & 0,4 & $0,3-0,6$ & $<0,001$ \\
\hline \multicolumn{8}{|l|}{ Minuman manis } \\
\hline$>1$ gelas per hari & 34 & 13,93 & 56 & 22,95 & 1,1 & $0,6-2,1$ & 0,648 \\
\hline$>2$ gelas per hari & 30 & 12,30 & 49 & 20,08 & 1,2 & $0,6-2,2$ & 0,640 \\
\hline$>3$ gelas per hari & 26 & 10,66 & 17 & 6,97 & 2,9 & $1,4-6,2$ & 0,006 \\
\hline$>4$ gelas per hari & 124 & 50,82 & 65 & 26,64 & 3,6 & $2,1-6,2$ & $<0,001$ \\
\hline
\end{tabular}

\section{BAHASAN}

Berdasarkan hasil penelitian pada karakteristik subjek penelitian yang berbeda secara signifikan antara siswa obes dan tidak obes adalah variabel jenis kelamin $(p=0,03)$. Beberapa penelitian juga menemukan hal yang sama $(14,15)$, namun belum ada penjelasan ilmiah mengenai hubungan obesitas dan jenis kelamin. Hal ini kemungkinan disebabkan oleh anak perempuan lebih sering membatasi makan dengan alasan penampilan dibandingkan anak laki-laki.

Dari hasil analisis bivariat terdapat perbedaan signifikan antara konsumsi air putih pada anak obes dan tidak obes dengan nilai OR 2,1. Hal ini berarti konsumsi air yang kurang, berpeluang terjadi 2,1 kali lebih besar pada anak obes dibandingkan anak non obes. Pada analisis multivariate, dapat dilihat hubungan konsumsi air putih dan minuman manis yang saling mempengaruhi, yaitu asupan minuman manis lebih dari $200 \mathrm{~mL} /$ hari akan menyebabkan kurangnya konsumsi air putih pada anak. Dengan demikian dapat disimpulkan bahwa konsumsi minuman manis pada anak obes lebih besar dibandingkan anak non obes.
Di California, promosi konsumsi air putih pada anakanak diusulkan untuk menggantikan konsumsi minuman manis sebab minuman manis diduga kuat sebagai penyebab terjadinya obesitas. Pemberian air putih pada anak diatur sedemikian rupa agar tidak mengganggu asupan makanan lain yang mengandung zat gizi penting untuk tumbuh kembang anak (16). Penelitian lain adalah pada anak sekolah dasar di dua daerah miskin di Jerman selama satu tahun ajaran dan hasilnya menemukan bahwa pemberian air putih yang disertai dengan edukasi manfaat air putih dapat mengurangi risiko obesitas sebesar $31 \%$ (17). Demikian pula penelitian lain yang juga menemukan bahwa penambahan konsumsi air $10 \mathrm{~mL} / \mathrm{kg}$ berat badan pada anak obes dapat meningkatkan (REE) sampai dengan $25 \%$. Dalam penelitian ini, ditemukan bahwa REE berhubungan secara signifikan dengan umur, tinggi badan, berat badan, dan massa lemak tubuh anak (18).

Program yang diterapkan melalui sekolah pada anak-anak di Australia dapat mengurangi faktor risiko terjadinya obesitas pada anak. Program ini bertujuan 
untuk mengubah perilaku konsumsi minuman manis dan makanan kurang sehat pada anak dengan menganjurkan anak untuk membawa bekal berupa air putih dan buahbuahan dalam bekal makan siangnya. Setelah 2 tahun, program ini dievaluasi dan ternyata berhasil merubah perilaku konsumsi anak dengan peningkatan 15-60\% anak membawa air putih ke sekolah dan mengurangi 8-38\% kebiasaan membawa minuman manis, dan 25$50 \%$ anak membawa buah segar dalam bekal makan siangnya (19).

Dalam penelitian ini, konsumsi susu dan produk susu tidak mempunyai hubungan dengan kejadian obesitas pada anak $(p>0,05)$. Sebuah studi longitudinal yang dilakukan pada remaja Amerika yang berumur 9-14 tahun menemukan bahwa anak yang minum susu lebih dari 3 gelas susu per hari mengalami kenaikan BMI dibandingkan anak yang mengkonsumsi susu kurang dari 3 gelas/hari. Dikemukakan juga bahwa susu merupakan minuman sehat untuk anak, walaupun dalam beberapa penelitian ditemukan bahwa dan estrone dalam produk susu menyebabkan kegemukan dan kalsium dalam susu dapat menurunkan berat badan (20).

Hasil uji Mc Nemar menunjukkan bahwa konsumsi minuman manis mempunyai hubungan signifikan dengan kejadian obesitas pada anak (OR 3,1: 95\% Cl: 2,1-4,5). Minuman manis telah dihubungkan dengan kejadian kenaikan berat badan yang signifikan pada anak-anak dan remaja. Kontribusi kalori dari minuman manis per kapita secara signifikan meningkat pada anak-anak dan remaja dengan $10 \%-15 \%$ total kalori harian berasal dari minuman manis seperti minuman bersoda, ,minuman energi, , minuman dengan rasa buah, dan jus konsentrat. Semua minuman ini memiliki kalori yang cukup tinggi dan menyebabkan obesitas. Jus buah konsentrat walaupun dipasarkan sebagai minuman sehat namun memiliki kalori yang cukup tinggi (21). Pengurangan konsumsi minuman jus buah konsentrat berhubungan dengan penurunan lemak tubuh dan dapat mencegah anak dari kegemukan (22).

Pada analisis multivariat yang menghubungkan konsumsi air putih dan minuman manis dengan jenis kelamin diketahui bahwa konsumsi air putih dan minuman manis saling mempengaruhi. Konsumsi minuman manis yang semakin tinggi menyebabkan konsumsi air putih menjadi sedikit, dan secara statistik kecenderungan konsumsi minuman manis lebih dari $200 \mathrm{~mL} /$ hari terjadi pada anak laki-laki. Sebuah penelitian yang dilakukan pada anak remaja di Amerika Serikat menemukan adanya hubungan antarkenaikan berat badan pada anak laki-laki akibat asupan minuman manis yang cenderung bertambah porsinya dari tahun sebelumnya dibandingkan dengan anak perempuan (23). Bertambahnya konsumsi minuman manis pada anak meningkatkan BMI anak secara signifikan (24). Dalam penelitian lainnya ditemukan bahwa minuman manis yang dikonsumsi lebih dari 3 porsi per hari dapat menggeser konsumsi minuman lain seperti susu dan air putih (25). Konsumsi air putih kurang dari $3 \mathrm{kali} /$ hari berhubungan dengan kualitas diet yang rendah termasuk meningkatnya konsumsi minuman diet soda $\geq 1 \mathrm{kali} /$ hari (OR 1,6 ), konsumsi minuman manis lainnya meningkat $\geq 1$ kali/hari (OR 1,4) (26).

\section{RUJUKAN}

1. Wahyu GG. Obesitas pada Anak. Jakarta: Bentang Pustaka (Mizan Group); 2009.

2. Hadi H. Beban ganda masalah gizi dan implikasinya terhadap kebijakan pembangunanan kesehatan nasional. Pidato Pengukuhan Jabatan Guru besar FK UGM. Yogyakarta: UGM; 2004.

3. Daniels MC, Popkin BM. Impact of water intake on energy intake and weight status: a systematic review. Nutrition Review 2010;68(9):505-21.

4. Hardinsyah H. Air sebagai zat gizi esensial, asupan dan masalahnya di Indonesia. Seminar pangan dan Gizi. Jakarta; 2012.

5. Jeong HE, Bish NC, Holloman C, Gordon KL. Evaluation of effectiveness of class-based nutrition intervention on changes in soft drink and milk consumption among young adults. Nutr J 2009;8:50.

6. Heaney RP, Davies KM, Barger-Lux MJ. Calcium and weight: clinical studies. J Am Coll Nutr 2002;21:152S155 S.

7. Carruth BR, Skinner JD. The role of dietary calcium and other nutrients in moderating body fat in preschool children. Int J Obes Relat Metab Disord 2001;25:55966.

8. Skinner JD, Bounds W, Carruth BR, Ziegler P. Longitudinal calcium intake is negatively related to children's body fat indexes. J Am Diet Assoc 2003;103:1626-31.

9. Pereira MA, Jacobs DRJ, Van Horn L, Slattery ML, Kartashov AI, Ludwig DS. Dairy consumption, obesity, and the insulin resistance syndrome in young adults: the CARDIA Study. JAMA 2002;287:2081-9.

10. Ludwig DS, Peterson KE, Gortmaker SL. Relation between consumption of sugar-sweetened drinks and childhood obesity: a prospective,observational analysis. The Lancet 2001;357(9255):505-8.

11. O'Connor TM, Yang SJ, Nicklas TA. Beverage intake among preschool children and its effect on weight status. Pediatr 2006;118(4):e1010-8.

12. Sullivan KM, May S, Maberly G. Urinary iodine assessment: a manual on survey and laboratory methods, 2nd ed. UNICEF, PAMM; 2000.

13. Kartono Dj, Hardinsyah, Jahari $A B$, Sulaeman $A$, Soekatri M. Penyempurnaan kecukupan gizi untuk orang Indonesia. Pokja AKG, Widyakarya Nasional Pangan dan Gizi X; 2012. 
14. Faizah Z. Faktor risiko obesitas pada murid sekolah dasar usia 6-7 tahun di Semarang, Institutional Repository. Semarang: Universitas Diponegoro; 2004. Available from URL: http://eprints.undip.ac.id/12326/

15. Sartika RAD. Faktor risiko obesitas pada anak 5-15 tahun di Indonesia. Makara Kesehatan 2011;15(1):37-43.

16. Ritchie L, Rausa J, Patel A, Guajardo EB, Hecht K. Providing water with meals is not a concern for young children. Summary of Literature and Best Practice Recommendations; 2012.

17. Muckelbauer R, Libuda L, Clausen K, Toschke AM, Reinehr T, Kersting M, Promotion and provision of drinking water in schools for overweight prevention: randomized, controlled cluster trial. Pediatrics 2009;123;e661.

18. Dubnov-Raz G, Constantini NW, H Yariof,Nice F, Shapira $\mathrm{N}$. Influence of water drinking on resting energy expenditure in overweight children. Int J Obes 2011.

19. Laurence S, Peterken R, Burns C. Fresh Kids: the efficacy of health promoting school approach to increasing consumption of fruit and water in Australia. Health Promotion International 2007;22(3).

20. Berkey CS, Rockett HRH, Willett WC, Colditz GA. Milk, dairy fat,dietary calcium and weight gain. Arch Pediatr Adolesc Med 2005;159:543-50.
21. Wang YC, Bleich SN, Gortmaker SL. Increasing caloric contribution from sugar-sweetened baverages and $100 \%$ fruit juices among US children and adolescents,1988-2004. Pediatr 2008;121;e1604.

22. Faith MS, Dennison BA, Edmunds LS, Stratton HH. Fruit juice intake predicts increased adiposity gain in children from low-income families: Weight status by environtment interaction; 2006. Available from URL: www. pediatrics.org/cgi/doi/10.1542/peds.1117.

23. Berkey CS, Rockett HRH, Field EA, Gillman Matthew, Colditz GA. Sugar-Added beverages and adolescent weight change. Obesity research 2004;12(5):778-88.

24. Blum JW, Jacobsen DJ, Donnelly JE. Baverage consumption patterns in elementary school aged children across a two-year period. J Am Coll Nutr 2005;24(2):93-8.

25. Malik VS, Schulze MB, Hu FB. Intake of sugar sweetened baverages and weight gain: a systematic review. Am J Clin Nutr 2006;84:274-88.

26. Park S, Blanck HM, Sherry B, Brener N, O'Toole T. Faktor associated with low water intake among US high school students-National Youth Physical Activuty and Nutrition Study. Elsevier Inc 2012;2212-672.Avo, C. Aximum pubit. Faciveris. 